\title{
Spatial and seasonal variations of fine particle water-soluble organic carbon (WSOC) over the southeastern United States: implications for secondary organic aerosol formation
}

\author{
X. Zhang ${ }^{1}$, Z. Liu ${ }^{1, *}$, A. Hecobian ${ }^{1, * *}$, M. Zheng ${ }^{2}$, N. H. Frank ${ }^{3}$, E. S. Edgerton ${ }^{4}$, and R. J. Weber ${ }^{1}$ \\ ${ }^{1}$ School of Earth and Atmospheric Sciences, Georgia Institute of Technology, Atlanta, Georgia, USA \\ ${ }^{2}$ College of Environmental Sciences and Engineering, Peking University, Beijing, China \\ ${ }^{3}$ Office of Air Quality Planning \& Standards, US Environmental Protection Agency, Research Triangle Park, \\ North Carolina, USA \\ ${ }^{4}$ Atmospheric Research \& Analysis, Inc., Cary, North Carolina, USA \\ *now at: Combustion Research Facility (CRF), Sandia National Laboratories, Livermore, California, USA \\ ** now at: Department of Atmospheric Science, Colorado State University, Fort Collins, Colorado, USA
}

Correspondence to: X. Zhang (xzhang3@gatech.edu)

Received: 19 March 2012 - Published in Atmos. Chem. Phys. Discuss.: 13 April 2012

Revised: 6 July 2012 - Accepted: 14 July 2012 - Published: 25 July 2012

\begin{abstract}
Secondary organic aerosol (SOA) in the southeastern US is investigated by analyzing the spatial-temporal distribution of water-soluble organic carbon (WSOC) and other $\mathrm{PM}_{2.5}$ components from 900 archived 24-h Teflon filters collected at 15 urban or rural EPA Federal Reference Method (FRM) network sites throughout 2007. Online measurements of WSOC at an urban/rural-paired site in Georgia in the summer of 2008 are contrasted to the filter data. Based on FRM filters, excluding biomass-burning events (levoglucosan $<50 \mathrm{ng} \mathrm{m}^{-3}$ ), WSOC and sulfate were highly correlated with $\mathrm{PM}_{2.5}$ mass $\left(r^{2} \sim 0.7\right)$. Both components comprised a large mass fraction of $\mathrm{PM}_{2.5}(13 \%$ and $31 \%$, respectively, or $\sim 25 \%$ and $50 \%$ for WSOM and ammonium sulfate). Sulfate and WSOC both tracked ambient temperature throughout the year, suggesting the temperature effects were mainly linked to faster photochemistry and/or synoptic meteorology and less due to enhanced biogenic hydrocarbon emissions. FRM WSOC, and to a lesser extent sulfate, were spatially homogeneous throughout the region, yet WSOC was moderately enhanced $(27 \%)$ in locations of greater predicted isoprene emissions in summer. A Positive Matrix Factorization (PMF) analysis identified two major source types for the summer WSOC; $22 \%$ of the WSOC were associated with ammonium sulfate, and $56 \%$ of the WSOC were associated with brown carbon and oxalate. A small urban ex-
\end{abstract}

cess of FRM WSOC (10\%) was observed in the summer of 2007, however, comparisons of online WSOC measurements at one urban/rural pair (Atlanta/Yorkville) in August 2008 showed substantially greater difference in WSOC (31\%) relative to the FRM data, suggesting a low bias for urban filters. The measured Atlanta urban excess, combined with the estimated boundary layer heights, gave an estimated Atlanta daily WSOC production rate in August of $0.55 \mathrm{mgC} \mathrm{m}^{-2} \mathrm{~h}^{-1}$ between mid-morning and mid-afternoon. This study characterizes the regional nature of fine particles in the southeastern US, confirming the importance of SOA and the roles of both biogenic and anthropogenic emissions.

\section{Introduction}

The US EPA reported that the annual mean temperature anomalies over the southern and southeastern US in the past century (1901 to 2005) were significantly lower than other parts of the country (http://www.epa.gov/climatechange/ science/recenttc.html). Meanwhile, Portmann et al. (2009) showed that changes in regional climate over the 20th century were most pronounced over the southern US. Previous studies based on in-situ and satellite observations of aerosol optical depth suggest that aerosols over these regions

Published by Copernicus Publications on behalf of the European Geosciences Union. 
may be the cause. The direct effects of aerosols on radiative forcing are estimated to produce a summertime cooling of $-11 \pm 6 \mathrm{~W} \mathrm{~m}^{-2}$ (Carrico et al., 2003) in urban Atlanta, and a greater radiative cooling of $-3.9 \mathrm{~W} \mathrm{~m}^{-2}$ in summer than in winter over the entire southeastern US (Goldstein et al., 2009). These estimates are significant compared to the global mean $\mathrm{CO}_{2}$ radiative forcing of $1.66 \mathrm{~W} \mathrm{~m}^{-2}$ and the global mean aerosol direct radiative forcing of $-0.5 \pm 0.4 \mathrm{~W} \mathrm{~m}^{-2}$ (IPCC, 2007). The southeastern US has the highest predicted biogenic emission of northern mid-latitudes (Fig. 1a), and the cooling haze over this region is thought to be largely from secondary organic aerosols (SOA) of biogenic origin (Goldstein et al., 2009). SOA is known to form from gasphase photo-oxidation of precursor volatile organic compounds (VOCs), including biogenic hydrocarbons, such as isoprene (Kroll et al., 2006) and monoterpenes (Hoffmann et al., 1997; Ng et al., 2007), as well as aromatic compounds (Odum et al., 1997) and possibly a host of other unidentified semi-volatile organic species from anthropogenic emissions (Robinson et al., 2007; de Gouw et al., 2011). Other processes may also play a role in SOA formation, such as synergistic interactions between biogenic and anthropogenic emissions (de Gouw et al., 2005; Weber et al., 2007) as well as SOA formation through cloud processing (Ervens et al., 2008) and condensed aqueous phase chemistry (Hennigan et al., 2009; Lim et al., 2010; Tan et al., 2010; Ervens et al., 2011).

The southeastern US has a generally rural environment interspersed with a number of urban areas, where, including the Atlanta metropolitan area, the fine particle $\left(\mathrm{PM}_{2.5}\right) \mathrm{Na}-$ tional Ambient Air Quality Standards (NAAQS) are often exceeded (Cohan et al., 2007). A number of ambient studies have been carried out to understand SOA formation over this region (Lee et al., 2010 and references therein). Based on ratios of organic carbon to elemental carbon (OC/EC), Lim and Turpin (2002) found that secondary OC (SOC) contributed approximately half of the measured OC in urban Atlanta, and the hourly contribution of SOC could occasionally range up to $88 \%$. Using water-soluble organic carbon (WSOC) as a measure of SOA carbon during summer, Weber et al. (2007) and Hennigan et al. (2009) reported similar SOC fractions, and those fractions were consistently higher $(\sim 75 \%)$ in rural areas due to reduced contributions of primary OC (Weber et al., 2007). Zheng et al. (2006) investigated the spatial distribution of carbonaceous aerosols in the southeast using molecular marker-based chemical mass balance (CMB-MM) modeling and found that the urban excess of OC was mainly from vehicle emissions and meat cooking based on results of the urban-rural pair in Alabama. Blanchard et al. (2011) also reported that most of the Atlanta urban excess OC was from motor vehicle emissions with a fossil carbon source based on analysis of SEARCH (Southeastern Aerosol Research and Characterization) filter data. Gao et al. (2006) analyzed polar organic components from 24-h filter samples collected at four SEARCH sites in the
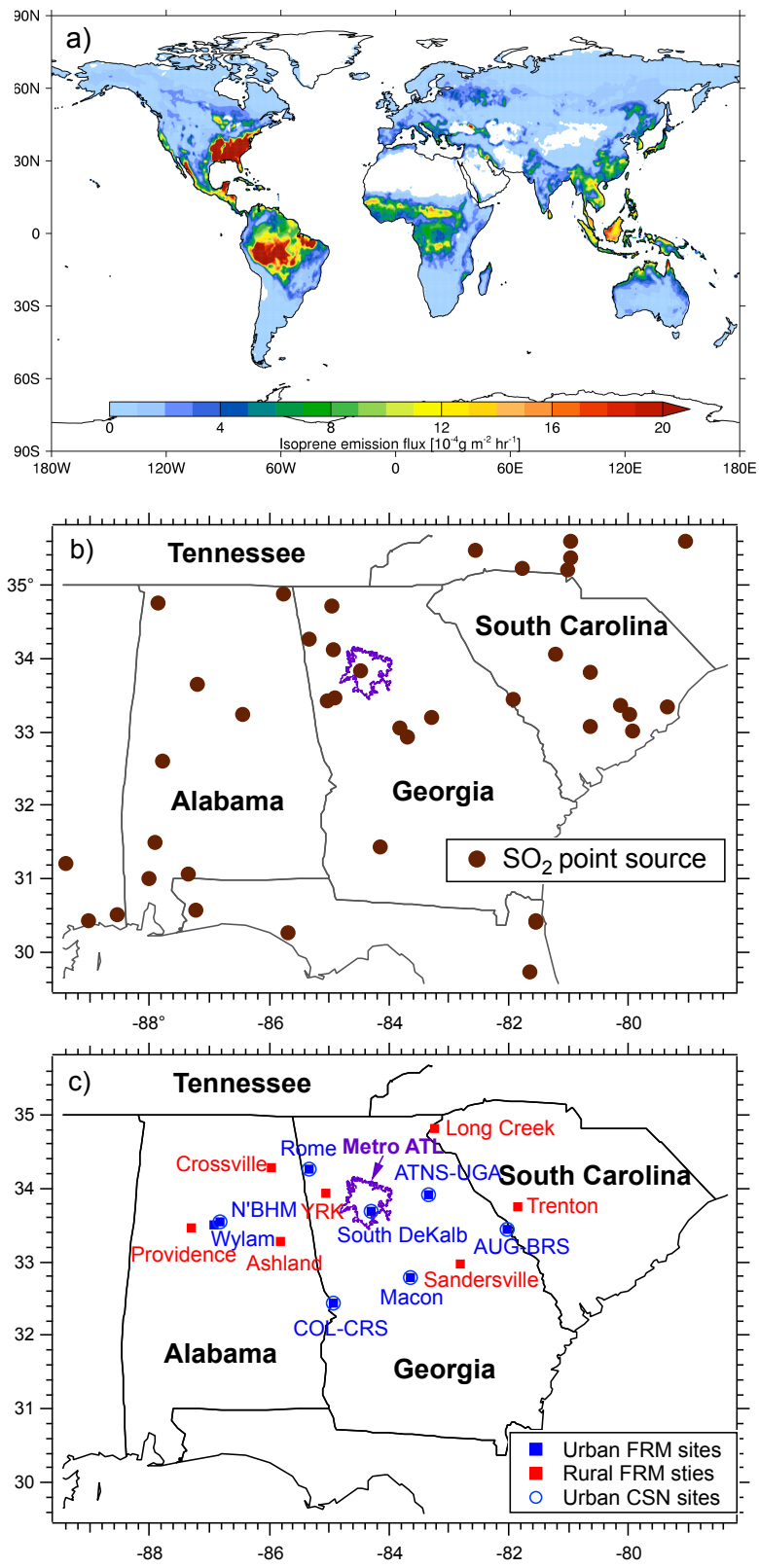

Fig. 1. Maps of (a) MEGAN-ECMWF global annual isoprene emissions in 2007, (b) $\mathrm{SO}_{2}$ point sources based on EPA National Emission Inventory (NEI) 1999, and (c) geographic locations of FRM and co-located CSN sampling sites.

summer of 2004 and found direct evidence for atmospheric processing of biogenic emissions (i.e. terpene oxidation) as a source of HUmic-LIke Substances (HULIS). Also based on filter samples collected at these four sites in 2004-2005, Ding et al. (2008) examined the spatial and seasonal trends of biogenic SOA tracers and found significant correlations between 2-methyltetrols, an isoprene oxidation product, and WSOC. Radiocarbon $\left({ }^{14} \mathrm{C}\right)$ analysis on $\mathrm{PM}_{2.5}$ WSOC collected in urban Atlanta in summer during periods of minimal 
biomass burning emissions showed that roughly 70 to $80 \%$ of the carbon in WSOC were modern rather than fossil. This suggested that most WSOC mass was linked to biogenic VOCs, assuming the main source of WSOC was SOA formation (Weber et al., 2007). Schichtel et al. (2007) estimated the average fraction of contemporary carbon was $92 \%$ in the summer and $81 \%$ in the winter of 2004 based on radiocarbon data from $\mathrm{PM}_{2.5}$ total carbon (OC and EC) collected at the Great Smoky Mountains National Park in Tennessee. However, most of these studies were based on filter samples with low time resolution collected from a limited number of sites over relatively short time periods and all are susceptible to filter sampling artifacts.

The findings in this paper add to these ambient results by investigating the spatial and seasonal variability of secondary aerosols over the southeastern US based on measurements of WSOC, sulfate and other $\mathrm{PM}_{2.5}$ chemical components extracted from 900 Federal Reference Method (FRM) filters collected at 15 sites throughout the year of 2007. These results demonstrate the potential of the large array of FRM filters collected by various regulatory agencies for investigating fine aerosol sources and properties of the non-volatile components. This paper focuses on non-biomass burning contributions to $\mathrm{PM}_{2.5}$; biomass-burning contributions based on this data set are presented elsewhere (Zhang et al., 2010). Additionally, one summer month of online WSOC and other gas and aerosol data with high time resolution sampled at an urban/rural paired site in Georgia in 2008 provide a complement to the 24-h integrated filter data and allow examination of SOA sources and formation on a much shorter time scale (diurnal) and with less susceptibility to sampling artifacts. The comparison of WSOC diurnal trends between urban and rural areas provides important insights on the roles of biogenic and anthropogenic emissions in SOA formation in the southeast.

\section{Methods}

\subsection{Filter sampling and measurements}

Fifteen FRM filter-sampling sites in the southeastern US were selected from the EPA FRM monitoring network. These sites are spread over three states (Alabama, Georgia, and South Carolina); eight are classified as urban and seven as rural sites based on their geographic locations and surrounding major emission sources (Fig. 1c). Zhang et al. (2010) provide a full list of the sites with name, location and type. A subset of the sites (seven of the eight urban sites and one rural site, Yorkville) was co-located EPA CSN (Chemical Speciation Network) sites with additional aerosol composition data available, including OC, EC and metals (Fig. 1c). A subset of FRM filter samples corresponding to every sixth day of sampling in 2007 yielded 60 filters per site and a total of 900 filters for analysis. Additionally, a series of field blanks
(36 filters) and replicated filters (43 filters) were included for quality control. $\mathrm{PM}_{2.5}$ mass concentrations were determined gravimetrically by the state regulatory agencies. The OC measurements (TOT NIOSH method) obtained from the subset of EPA CSN sites were not adjusted for possible positive sampling artifacts and thus represented an upper estimate of ambient OC. The following chemical analyses were performed after the filters had been archived for roughly a year (in the dark at a $T<-20^{\circ} \mathrm{C}$ ) and are restricted to watersoluble species extracted from the Teflon filters.

Detailed descriptions of filter extraction and the subsequent analytical methods were presented elsewhere (Zhang et al., 2010). Briefly, each filter was extracted in $30 \mathrm{ml}$ of $18-\mathrm{M} \Omega$ Milli-Q water via $30 \mathrm{~min}$ sonication. The liquid extract was then filtered using a $0.45 \mu \mathrm{m}$ PTFE disposable syringe filter. WSOC in the liquid extract was quantified with a Sievers Total Organic Carbon (TOC) analyzer (GE Water Systems, Boulder, $\mathrm{CO}$ ) with a method limit of detection (LOD) of $0.33 \mu \mathrm{g}$ Carbon $\mathrm{m}^{-3}\left(\mu \mathrm{gC} \mathrm{m}^{-3}\right)$ and an overall measurement uncertainty of $9 \%$. Levoglucosan and other carbohydrate compounds were quantified using a Dionex High-Performance Anion-Exchange Chromatography with Pulsed Amperometric Detection (HPAEC-PAD). Compound separation was achieved with a Dionex CarboPac PA-1 column and gradient elution of $200 \mathrm{mM} \mathrm{NaOH}$ (Zhang et al., 2010). Water-soluble cations (sodium, ammonium, potassium and magnesium) and anions (chloride, sulfate and oxalate) were measured with a dual-channel Dionex DX-500 Ion Chromatograph with a Dionex CS12A cation column and a Dionex AS11-HC anion column. Light absorption spectra of the bulk liquid extracts were determined using a UV/Vis spectrophotometer with long-path $(1 \mathrm{~m})$ Liquid Waveguide Capillary Cell (LWCC-2100, World Precision Instrument, Sarasota, FL). The average bulk absorption between wavelengths 360 and $370 \mathrm{~nm}\left(b_{\text {ap } 365}\right.$, in units of $\left.\mathrm{m}^{-1}\right)$ was used as a measure of soluble brown carbon light absorption. Hecobian et al. (2010) provide a detailed description of the method and results of brown carbon sources, based in part on the FRM filters used in this work.

FRM Teflon filters are not ideal for ambient $\mathrm{PM}_{2.5}$ composition measurements since the un-denuded sampling method may contribute to artifacts. The yearlong storage may also lead to loss of semi-volatile components (e.g. nitrate, semivolatile OC) (Watson et al., 2009). A comparison between FRM NH$H_{4}^{+}$and $\mathrm{NH}_{4}^{+}$measured from nylon filters from colocated $\mathrm{CSN}$ sites showed that $\mathrm{CSN} \mathrm{NH}_{4}^{+}$concentrations were on average $15 \%$ higher than $\mathrm{FRM} \mathrm{NH}_{4}^{+}$concentrations (corresponding to a linear regression slope of 1.15), reflecting possible loss of semi-volatile $\mathrm{NH}_{4}^{+}$associated with $\mathrm{NO}_{3}^{-}$ from the FRM filters (Zhang et al., 2010). Thus, nitrate measurement from FRM filters is not deemed reliable and the reported WSOC and other components (including $\mathrm{PM}_{2.5}$ mass) should be viewed as a measure of the less volatile species associated with ambient $\mathrm{PM}_{2.5}$. 


\subsection{Online measurements}

From 2 August to 15 September 2008, as part of the $2008 \mathrm{Au}-$ gust Mini-Intensive on Georgia Aerosol at SEARCH (AMIGAS) field study, online $\mathrm{PM}_{2.5}$ WSOC measurements were conducted using a Particle-Into-Liquid Sampler (PILS) coupled with a TOC analyzer (Sullivan et al., 2004) simultaneously at two SEARCH sites in Georgia, i.e. Jefferson Street (JST) and Yorkville (YRK). JST $\left(33.777^{\circ} \mathrm{N}, 84.416^{\circ} \mathrm{W}\right)$ is an urban site approximately $4 \mathrm{~km}$ northwest of central Atlanta and is located in a mixed commercial/residential area. YRK $\left(33.929^{\circ} \mathrm{N}, 85.045^{\circ} \mathrm{W}\right)$ is a rural site approximately $55 \mathrm{~km}$ northwest of metro Atlanta. Detailed description of the sampling sites was given by Hansen et al. (2003). The ambient fine particles were concentrated into a continuous liquid flow via a PILS with an upstream URG PM 2.5 cyclone and a parallel plate carbon denuder (Eatough et al., 1993). Three background WSOC measurements were performed daily (at 03:00, 10:00 and 19:00 EST) throughout the study period by diverting the sampling flow through a Teflon filter $(47 \mathrm{~mm}$ dia., $2.0 \mu \mathrm{m}$ pore size, Pall Life Sciences). Ambient WSOC data were blank-corrected and reported at 10-min resolution. The limit of detection (LOD) for WSOC was approximately $0.1 \mu \mathrm{gC} \mathrm{m}{ }^{-3}$ and the overall measurement uncertainty $\sim 10 \%$. During the AMIGAS campaign, WSOC data at both sites were available for 25 days from 12 August to 6 September 2008, along with a suite of gas and meteorological data that were routinely measured at these SEARCH sites.

The two PILS-TOC systems deployed at the two SEARCH sites were compared side-by-side prior to and after the field campaign on the roof of the Environmental Science and Technology building on the Georgia Institute of Technology campus for a period of 4 days. The data collected by the two instruments were highly correlated $\left(r^{2}=0.96\right)$ and showed good agreement with a linear regression slope of 0.88 and an intercept of $0.13 \mu \mathrm{gC} \mathrm{m} \mathrm{m}^{-3}$. The YRK WSOC data were modified to account for this small systematic difference.

\subsection{Gridded monthly isoprene emission fluxes from MEGAN-ECWMF global inventory}

Monthly averaged isoprene emission data over the southeast (30-36 $\mathrm{N}, 80-89^{\circ} \mathrm{W}$ ) were obtained from the website: http: //tropo.aeronomie.be/models/isoprene.htm. The global emissions of isoprene were calculated at $0.5^{\circ}$ resolution, based on the MEGAN (Model of Emissions of Gases and Aerosols from Nature) version 2 (Guenther et al., 2006) and a detailed multi-layer canopy environment model for the calculation of leaf temperature and visible radiation fluxes. The calculation was driven by meteorological fields provided by analyses of the European Centre for Medium-Range Weather Forecasts (ECMWF) (Müller et al., 2008) and included air temperature, cloud cover, downward solar irradiance, wind speed, and volumetric soil moisture in four soil layers.

\section{Results and discussion}

\subsection{Characteristics of fine aerosol composition over the southeast - a "sulfate-organic-rich" fine aerosol with widely uniform concentrations}

Seasonal average mass concentrations of $\mathrm{PM}_{2.5}$ and a number of its key chemical components at each of the 15 sampling sites are presented in Fig. 2. Levoglucosan, an exclusive and relatively stable biomass burning emission tracer, had a large cold-warm season contrast due to enhanced domestic biomass burning emissions in the winter, as can be seen from the generally higher levoglucosan concentrations at urban sites, as well as more frequent wildfires and prescribed burnings in winter and spring; the large inter-site variability was due to random plume impacts (see Zhang et al. (2010) for a detailed discussion of biomass burning emissions from this data set). A possible secondary effect of accelerated loss of levoglucosan via photo-oxidation in the summer (Hennigan et al., 2010) may also account for some of the seasonal difference. To minimize the contribution of biomass burning to primary WSOC (WSOC $\mathrm{BB}_{\mathrm{BB}}$ ) and focus on secondary WSOC, a surrogate of SOA carbon (Sullivan et al., 2004, 2006; Hennigan et al., 2009; Miyazaki et al., 2009), filter samples with levoglucosan concentration greater than $50 \mathrm{ng} \mathrm{m}^{-3}$ were not included in the following analysis and discussion. The remaining data were assumed to be largely non-biomass-burning WSOC $\left(\mathrm{WSOC}_{\mathrm{NB}}\right)$, which in warmer seasons was mainly comprised of secondary WSOC, with minor contributions of primary WSOC from mobile source emissions at urban sites (Hecobian et al., 2010). In colder seasons, the fraction of primary $\mathrm{WSOC}_{\mathrm{NB}}$ could be higher due to reduced secondary WSOC formation from photochemistry.

Organic material (OM) (calculated by assuming an $\mathrm{OM} / \mathrm{OC}$ ratio of 1.6) and ammonium sulfate were the two largest components of $\mathrm{PM}_{2.5}$ mass throughout the year at all sites (Table 1), consistent with previous studies (Tanner et al., 2004; Weber et al., 2007; Hand et al., 2012). On average, OM and ammonium sulfate accounted for $39 \pm 6 \%$ and $50 \pm 5 \%$ of the total $\mathrm{PM}_{2.5}$ mass, respectively. The minor contributors to $\mathrm{PM}_{2.5}$ mass included $\mathrm{EC}(\sim 7 \%$ in urban areas) and other refractory materials such as mineral dust and sea salt that were enriched in $\mathrm{K}^{+}$and $\mathrm{Mg}^{2+}(6 \%$ from a PMF analysis detailed by Zhang et al., 2010).

Scatter plots in Fig. 3 show the tight correlations of WSOC $_{\mathrm{NB}}$ and sulfate with $\mathrm{PM}_{2.5}$ mass in urban and rural sites. The high $R^{2}$ values for both $\mathrm{WSOC}_{\mathrm{NB}}(0.70$ at urban to 0.75 at rural sites) and sulfate ( 0.60 at urban to 0.66 at rural sites) with $\mathrm{PM}_{2.5}$ mass indicate the widespread presence of these two $\mathrm{PM}_{2.5}$ components throughout the southeast. Contributions from primary species to the total fine aerosol mass likely account for the slightly lower regression slopes and $R^{2}$ values for both components at urban sites (Fig. 3). Assuming a WSOM/WSOC ratio of 2.0 (Turpin and Lim, 2001), 
Table 1. Annual and seasonal average $\mathrm{WSOC}_{\mathrm{NB}} / \mathrm{OC}_{\mathrm{NB}}$ mass ratios and fractions (\%) of organic material (OM), ammonium sulfate, and water-soluble organic material (WSOM) in $\mathrm{PM}_{2.5}$, where $\mathrm{OM}$ is $1.6 \times \mathrm{OC}$, WSOM is $2.0 \times \mathrm{WSOC}$, and the subscript NB represents nonbiomass-burning, using levoglucosan concentration (less than $50 \mathrm{ng} \mathrm{m}^{-3}$ ) as a criteria.

\begin{tabular}{|c|c|c|c|c|c|c|c|c|}
\hline & \multicolumn{2}{|c|}{$\mathrm{OM} / \mathrm{PM}_{2.5}$ mass } & \multicolumn{2}{|c|}{$\left(\mathrm{NH}_{4}\right)_{2} \mathrm{SO}_{4} / \mathrm{PM}_{2.5}$ mass } & \multicolumn{2}{|c|}{$\mathrm{WSOM}_{\mathrm{NB}} / \mathrm{PM}_{2.5}$ mass } & \multicolumn{2}{|c|}{$\begin{array}{c}\mathrm{WSOC}_{\mathrm{NB}} / \mathrm{OC}_{\mathrm{NB}} \\
\left(\text { levog. }<50 \mathrm{ng} \mathrm{m}^{-3}\right)\end{array}$} \\
\hline & Urban & Rural* & Urban & Rural & Urban & Rural & Urban & Rural $^{*}$ \\
\hline Annual & 43.7 & 34.7 & 40.7 & 50.4 & 23.5 & 26.3 & 51.9 & 55.8 \\
\hline Winter & 44.0 & 34.3 & 32.8 & 41.4 & 20.2 & 25.5 & 45.2 & 59.6 \\
\hline Spring & 49.1 & 33.2 & 39.7 & 47.0 & 24.8 & 26.7 & 46.8 & 41.2 \\
\hline Summer & 40.9 & 36.1 & 49.1 & 53.6 & 26.4 & 28.9 & 56.3 & 52.6 \\
\hline Fall & 40.5 & 33.1 & 46.2 & 56.7 & 22.9 & 24.3 & 51.2 & 69.7 \\
\hline
\end{tabular}

* $\mathrm{OM}(\mathrm{OC})$ data are only available at one rural site: Yorkville (YRK).

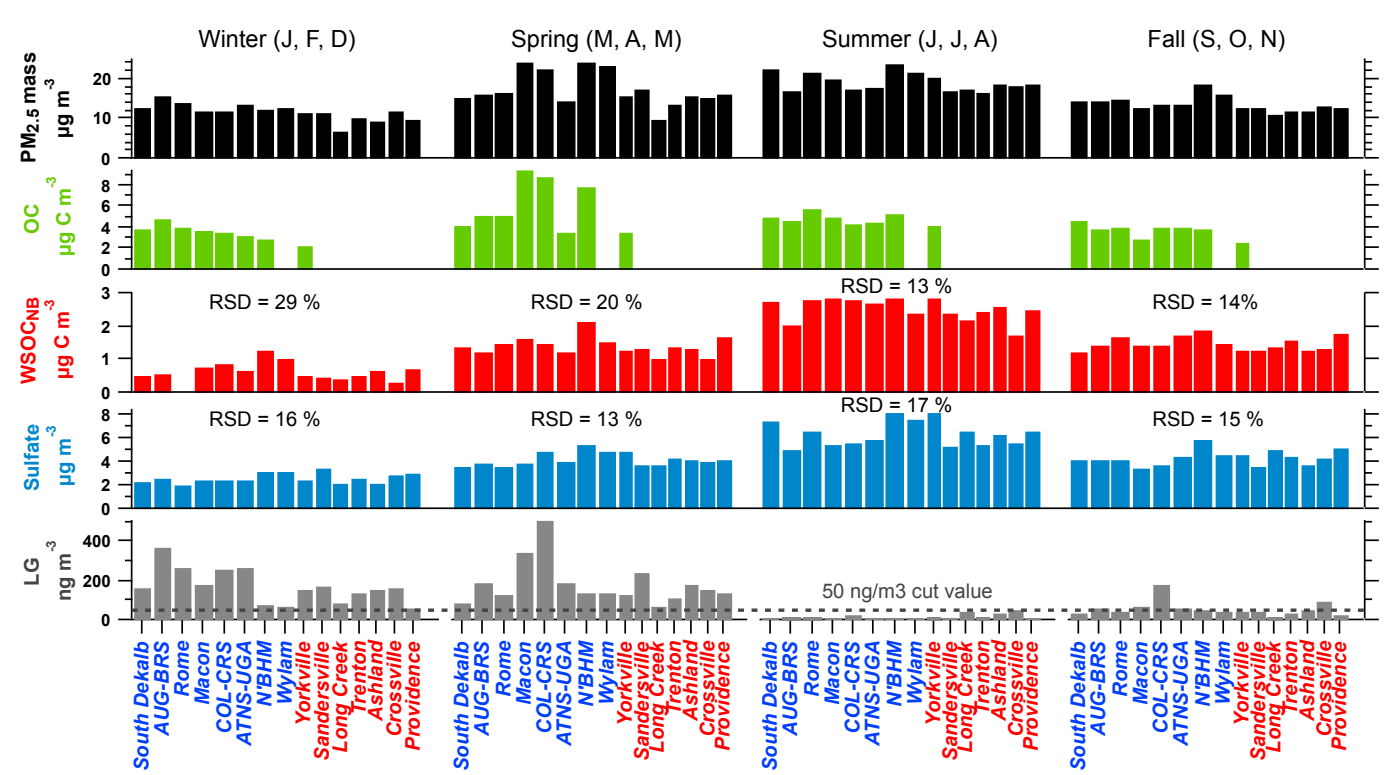

Fig. 2. Seasonal mean concentrations of (a) $\mathrm{PM}_{2.5}$ mass, (b) OC, (c) $\mathrm{WSOC}_{\mathrm{NB}}$, (d) sulfate and (e) levoglocosan (LG) for all 15 FRM sampling sites. OC data are only available at 7 of the 8 urban sites and 1 rural site. RSD stands for seasonal average relative standard deviations of $\mathrm{WSOC}_{\mathrm{NB}}$ and sulfate data. The initials after each season indicate the months included. Urban sites are labeled in blue and rural sites are labeled in red.

WSOM $_{\mathrm{NB}}$ (a proxy of SOA mass) and ammonium sulfate together contributed up to $76 \%$ at urban and $82 \%$ at rural sites of the total $\mathrm{PM}_{2.5}$ mass in the summer (Table 1). The large mass fractions of $\mathrm{WSOM}_{\mathrm{NB}}$ and sulfate and their strong correlations with $\mathrm{PM}_{2.5}$ mass imply that the secondary processes leading to the formation of both components largely influence and contribute substantially to the fine particle loadings over the southeast throughout the year, which has significant implications on $\mathrm{PM}_{2.5}$ control strategies and possible $\mathrm{PM}_{2.5}$ responses to a changing climate (Goldstein et al., 2009).

\subsection{Seasonal and spatial variability of WSOC based on FRM filter data}

\subsubsection{Seasonality of WSOC and other $\mathrm{PM}_{2.5}$ components}

The monthly mean concentrations of $\mathrm{WSOC}_{\mathrm{BB}}$ and WSOC $_{\mathrm{NB}}$ shown in Fig. 4 indicated that the biomass burning influences on WSOC were mostly in winter and spring, whereas during summer and early fall (September and October), $\mathrm{WSOC}_{\mathrm{BB}}$ was nearly negligible. Pronounced seasonality for concentrations of $\mathrm{PM}_{2.5}$ mass (Fig. 2), $\mathrm{WSOC}_{\mathrm{NB}}$ and sulfate were found, with maximum in summer and minimum in winter. The mean summer (JJA)-to-winter (JFD) ratio ( \pm one standard deviation) averaged across all 

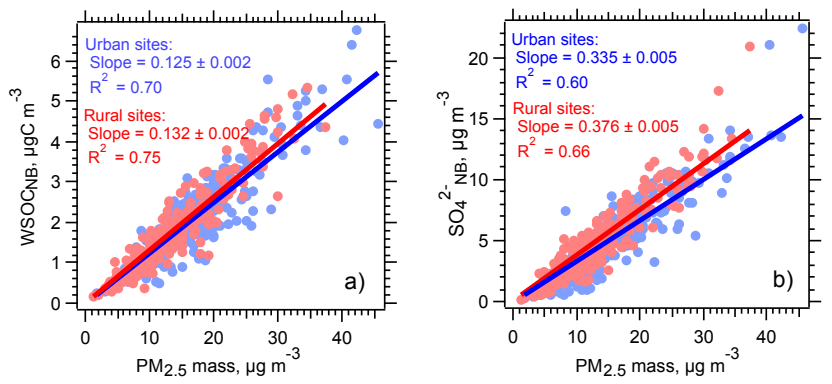

Fig. 3. Scatter plots of (a) $\mathrm{WSOC}_{\mathrm{NB}}$ and (b) Sulfate $\mathrm{NB}$ (nonbiomass-burning) versus $\mathrm{PM}_{2.5}$ mass concentrations. Slope and $R^{2}$ of the linear fit are shown separately for urban and rural sites.

the sites for sulfate, WSOC and OC concentrations was $2.5 \pm 0.6,1.9 \pm 0.8$, and $1.6 \pm 1.1$, respectively. When filtering out samples with significant levoglucosan concentrations $\left(>50 \mathrm{ng} \mathrm{m}^{-3}\right.$ ) to remove biomass-burning influence, these ratios were nearly doubled, i.e. $4.5 \pm 0.4$ for sulfate, $3.9 \pm 0.5$ for WSOC, and $2.2 \pm 0.9$ for OC. A lower summer/winter ratio for OC may reflect that roughly half OC was primary at urban sites (although less at rural sites), which was not expected to vary significantly with season (Lim and Turpin, 2002; Weber et al., 2007). In contrast, the large summerwinter difference for $\mathrm{WSOC}_{\mathrm{NB}}$ and sulfate concentrations was most likely due to the summertime enhancement of secondary chemical processes (e.g. enhanced photochemistry due to higher oxidant levels and stronger solar radiation). As shown in Fig. 4, $\mathrm{WSOC}_{\mathrm{NB}}$ and temperature (and to a lesser extent, sulfate and temperature) had a common seasonal pattern (for $\mathrm{WSOC}_{\mathrm{NB}}$ vs. $T: r^{2}=0.57$; sulfate vs. $T r^{2}=0.38$ ), and there was a clear co-variability among these three from March to August; an unusually warm March had elevated $\mathrm{WSOC}_{\mathrm{NB}}$ and sulfate, whereas a cooler July corresponded to lower concentrations. Much of this co-variability may be due to temperature effects on photochemistry and synoptic meteorology. The enhanced emissions of precursor compounds (e.g. isoprene as a SOA precursor) during warmer months may also explain some of the seasonality observed for WSOC. Studies have found evidence for biogenic hydrocarbons as a major contributor of SOA mass over the southeast (Gao et al., 2006; Weber et al., 2007; Ding et al., 2008; Goldstein et al., 2009; Chan et al., 2010b; Lin et al., 2012). Monthly mean predicted isoprene emission shown in Fig. 4 had a large seasonal variability and roughly increased 4 fold from winter to summer. However, since sulfate also exhibited an evident seasonality, yet $\mathrm{SO}_{2}$ emissions did not have a strong seasonal dependence (US EPA National Emissions Inventory, http://www.epa.gov/ttnchie1/trends/), the seasonal variability of $\mathrm{WSOC}_{\mathrm{NB}}$ based on 24-h filter data cannot be related specifically to temperature-induced biogenic emissions and resulting SOA formation. The observed seasonality for $\mathrm{WSOC}_{\mathrm{NB}}$ and sulfate may be due to a combination of various controlling factors, including synoptic meteoro-

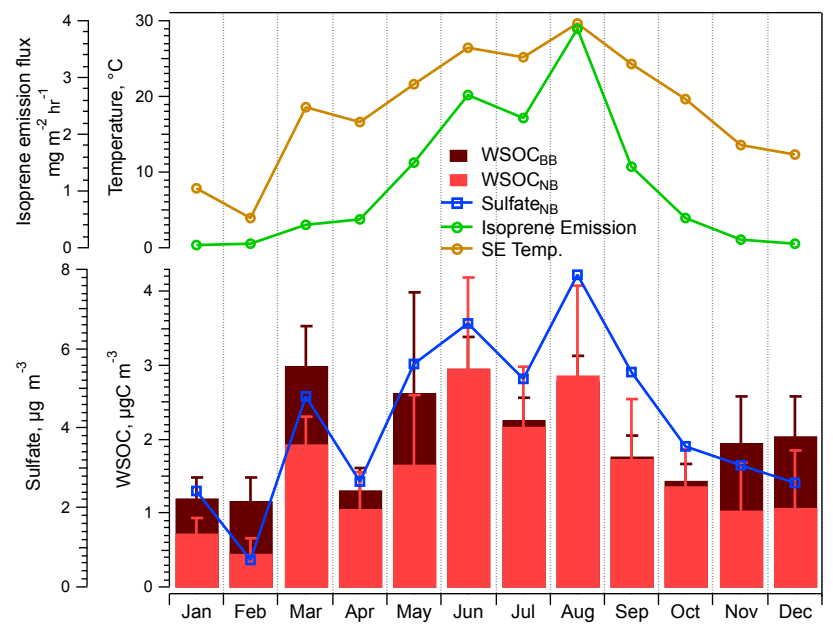

Fig. 4. Monthly mean concentrations of $\mathrm{WSOC}_{\mathrm{BB}}$ and $\mathrm{WSOC}_{\mathrm{NB}}$, sulfate and temperature averaged over all sampling sites; regional average isoprene emission flux over the sampling domain (30$\left.36^{\circ} \mathrm{N}, 80-89^{\circ} \mathrm{W}\right)$.

logical events (e.g. stagnation and precipitation), transport and photochemistry. Emissions of precursor compounds may also play a role, but is probably minor from the analysis of this data set.

\subsubsection{Spatial homogeneity of WSOC and sulfate}

One of the notable features of Fig. 2 is the insignificant site-to-site variation of $\mathrm{WSOC}_{\mathrm{NB}}$ and sulfate concentrations throughout all seasons, especially during warmer months. This is indicative of widely uniform concentrations of both secondary components throughout the region. Seasonally averaged relative standard deviations (RSD; standard deviation divided by mean for the season of interest) for $\mathrm{WSOC}_{\mathrm{NB}}$ and sulfate, as labeled in Fig. 2 above each group, were mostly below $20 \%$ except for $\mathrm{WSOC}_{\mathrm{NB}}$ in the winter. A detailed site-to-site correlation analysis suggests that the concentrations of $\mathrm{WSOC}_{\mathrm{NB}}$ and sulfate were not only similar but also well correlated to those at other sites. Taking the South Dekalb (urban Atlanta) site as an example since it is located in the center of the sampling region, Fig. 5 shows the correlation coefficients $\left(r^{2}\right)$ of WSOC $\mathrm{NB}$ and sulfate concentration between South Dekalb and each of the other 14 sites as a function of estimated distance between sites. WSOC $\mathrm{NB}$ at South Dekalb was strongly correlated with that at all other sites as indicated by the high $r^{2}$ values $(>0.65)$. For example, for the Providence site, a rural site $\sim 280 \mathrm{~km}$ away from South Dekalb, the $r^{2}$ of $\mathrm{WSOC}_{\mathrm{NB}}$ was as high as 0.93 , suggesting the highly spatial homogeneity of $\mathrm{WSOC}_{\mathrm{NB}}(\mathrm{SOA})$, similar to previous finding by Ding et al. (2008). The site-tosite correlation for sulfate was weaker than $\mathrm{WSOC}_{\mathrm{NB}}$, possibly owing to the spatial distribution of the $\mathrm{SO}_{2}$ point source (Fig. 1b). For example, the very low $r^{2}$ of sulfate between 


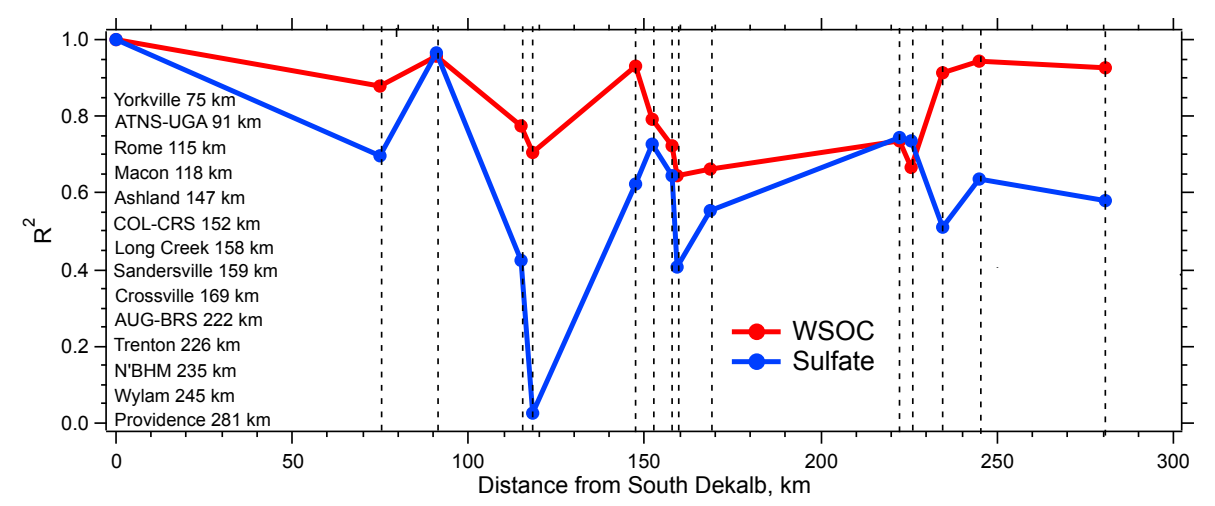

Fig. 5. Site-to-site correlations of WSOC and sulfate between South Dekalb (a site within urban Atlanta) and other 14 sites in the southeast. Distance between South Dekalb and the other site is given in ascending order.

South Dekalb and Macon may be partially due to the large coal-fired power plant near the Macon site. For all the combination of 15 sites $(N=105)$, the mean (median) \pm standard deviation of $r^{2}$ value was $0.64(0.69) \pm 0.25$ for $\mathrm{WSOC}_{\mathrm{NB}}$ and $0.46(0.48) \pm 0.28$ for sulfate.

The observed large seasonal variation and spatial homogeneity of FRM filter-based WSOC (i.e. non-volatile WSOC) is consistent with biogenic VOC emissions that are both highly temperature dependent and widely distributed over the southeast. These patterns, together with observations of organic carbon in this region having a large modern (i.e. biogenic) carbon component (Tanner et al., 2004; Weber et al., 2007; Bench et al., 2007; Schichtel et al., 2007), support the hypothesis that biogenic VOC oxidation is the major SOA source in the southeast. However, similar (although to a lesser degree) seasonality and spatial uniformity have been observed for sulfate. Sulfate is formed from oxidation of $\mathrm{SO}_{2}$, and the largest source of national $\mathrm{SO}_{2}$ emission is coal-fired electric power plants, accounting for $73 \%$ of the total $\mathrm{SO}_{2}$ emission in 2007 (US EPA National Emissions Inventory). As shown in Fig. $1 \mathrm{~b}$, the $\mathrm{SO}_{2}$ point sources in the southeast are not uniformly distributed, unlike the VOCemitting vegetation. Thus, as discussed in Sect. 3.2.1, it is more likely the observed spatial homogeneity for these secondary compounds is largely due to meteorology, resulting in a well-mixed regional aerosol characteristic of the southeast. Both WSOC (SOA) and sulfate are long-lived secondary products with lifespan of days to a week. The southeast region is generally not well ventilated (unlike the coastal areas where the sea/land breeze circulation disperses the pollution daily, Zhang et al., 2012), especially during summer when high-pressure systems lead to frequent stagnation events. Therefore, the pollutants with long lifetime, such as SOA and sulfate, can build up and eventually spread across the whole southeast region. Thus, the regional $\mathrm{WSOC}_{\mathrm{NB}}$ per se does not exclusively indicate a widely distributed source of SOA (i.e. biogenic VOC oxidation). An alternative explanation is that the formation of $\mathrm{WSOC}_{\mathrm{NB}}$ is not independent of

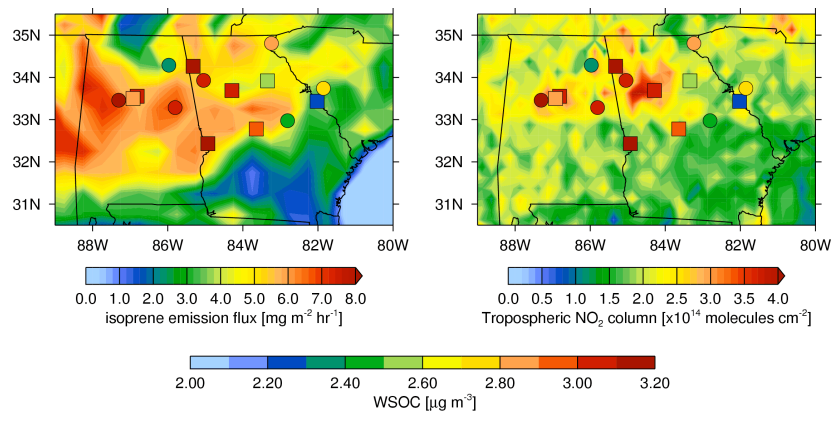

Fig. 6. Spatial distributions of (a) isoprene emission fluxes $\left(0.5^{\circ} \times 0.5^{\circ}\right)$ predicted from MEGAN-ECWMF global inventory and (b) tropospheric $\mathrm{NO}_{2}$ column density from OMI on board NASA AURA satellite in August of 2007. Overlaid on the emission maps are the color-coded WSOC $_{\mathrm{NB}}$ concentrations at the 15 FRM sampling sites (urban: squares; rural: circles) in August 2007 (Note that the $\mathrm{WSOC}_{\mathrm{NB}}$ color scale is set to investigate relatively small changes in absolute $\mathrm{WSOC}_{\mathrm{NB}}$ concentrations).

sulfate (e.g. WSOC formed through acid-catalyzed reaction) so the uniform distribution of sulfate has some impact on SOA formation and thus the distribution of $\mathrm{WSOC}_{\mathrm{NB}}$. Recent work by Lin et al. (2012) found that reactive uptake of gaseous isoprene-derived epoxydiols (IEPOX) onto acidic seed aerosols yielded the same aerosol constituents that have been observed in the ambient aerosols in rural southeast. A study contrasting regional distributions of $\mathrm{WSOC}_{\mathrm{NB}}$ and a primary species such as EC would provide additional insight.

\subsubsection{Spatial correlations of WSOC concentrations with isoprene emissions}

Although $\mathrm{WSOC}_{\mathrm{NB}}$ was highly correlated and relatively uniformly distributed throughout the whole region, some of the spatial pattern may be linked to the spatial distribution of isoprene emissions. Figure 6a shows the color-coded mean predicted isoprene emission flux with $\mathrm{WSOC}_{\mathrm{NB}}$ concentrations at each sampling site for August 2007. In August, 


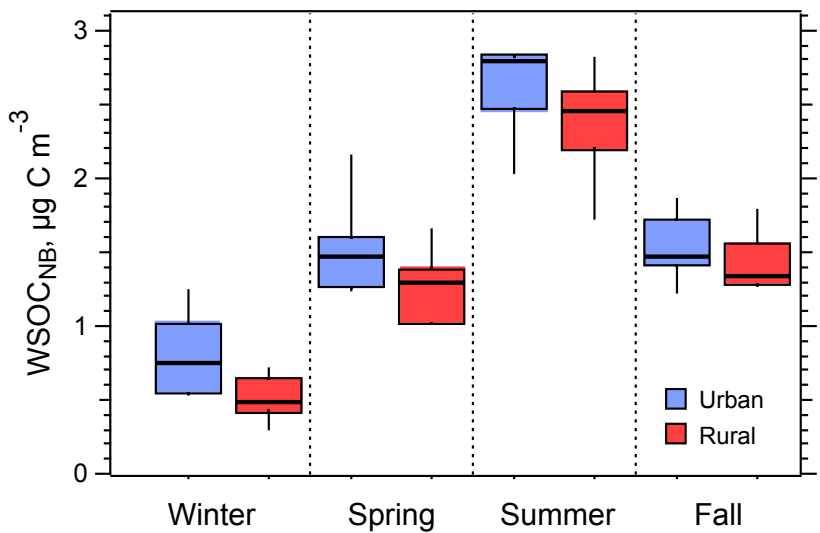

Fig. 7. Box plots of the seasonal mean concentrations of $\mathrm{WSOC}_{\mathrm{NB}}$ segregated for urban and rural sites. The plot shows median values (thick horizontal bar), 25th and 75th percentiles (lower and upper box bounds, respectively), and 10th and 90th percentiles (lower and upper whiskers, respectively) for each bin.

biogenic emissions and SOA formation are significant due to the large vegetation mass, high temperature and intense solar radiation. Quantitative interpretations from Fig. 6a are limited by the coarse grids $\left(0.5^{\circ} \times 0.5^{\circ}\right)$ and known large uncertainties for isoprene emission estimates (Guenther et al., 2006). However, some qualitative trends can be seen in Fig. 6a. First, there was a rough west-to-east gradient in isoprene emissions and a corresponding $\mathrm{WSOC}_{\mathrm{NB}}$ zonal trend. WSOC $_{\mathrm{NB}}$ concentrations were lower by roughly $27 \%$ at the five sites on the east end of the sampling region, which were also located in areas with less isoprene emissions. On smaller spatial scales, isoprene enhanced areas often corresponded to high $\mathrm{WSOC}_{\mathrm{NB}}$ (e.g. COL-CRS, Ashland and the three most western sites in AL). Interestingly, there were several sites in the vicinity of urban Atlanta that exhibited high WSOC $_{\mathrm{NB}}$ concentrations yet were not in isoprene-enriched areas. It is possible that these sites were under stronger influence of anthropogenic emissions as seen from the satellite observed $\mathrm{NO}_{2}$ column density in Fig. 6b. Previous ambient studies have shown evidence for enhanced SOA formation from interactions between naturally emitted precursors with anthropogenic pollutants such as $\mathrm{NO}_{\mathrm{x}}$ (Weber et al., 2007; de Gouw et al., 2008; Worton et al., 2011). Environmental chamber studies also reported higher SOA yields for biogenic hydrocarbons in the presence of high $\mathrm{NO}_{\mathrm{x}}$ levels (Dommen et al., 2006; Chan et al., 2010a). Contributions from anthropogenic SOA formation in urban regions would also account for higher urban WSOC. The extent of the contribution from pure anthropogenic or anthropogenicenhanced biogenic SOA to urban WSOC in the southeast is discussed elsewhere (Zhang et al., 2011, 2012) as well as in the following section.

\subsection{WSOC concentration gradient between urban and rural sites based on FRM filter data and online WSOC measurements}

\subsubsection{Urban/rural FRM WSOC}

A small urban/rural gradient of FRM WSOC $\mathrm{NB}_{\mathrm{NB}}$ was evident for all four seasons (Fig. 7), indicating an anthropogenic component for primary $\mathrm{WSOC}_{\mathrm{NB}}$ and/or SOA production in urban environments, consistent with the reported urban excess OC in the southeast (Zheng et al., 2006; Blanchard et al., 2011; Hand et al., 2012). The largest urban/rural difference was seen in winter (on average urban $\mathrm{WSOC}_{\mathrm{NB}}$ is $63 \%$ higher than rural $\mathrm{WSOC}_{\mathrm{NB}}$ ), whereas in other seasons the difference was within $20 \%$. The much higher urban $\mathrm{WSOC}_{\mathrm{NB}}$ in the winter was likely due to primary WSOC emitted from fossil fuel combustion and possibly residential wood burning (although data with leveoglucosan $>50 \mathrm{ng} \mathrm{m}^{-3}$ were filtered out) in urban areas. Based on the FRM filter data, the widespread SOA was only moderately enhanced by urban emissions, resulting in a small urban/rural gradient $(10 \%)$ in the summer. However, as noted earlier, FRM filter sampling is subject to considerable negative artifact so that the semi-volatile SOA components may not be included. An online measurement is expected to have less sampling artifacts (Weber et al., 2003). Factors associated with the summer urban/rural difference were explored by conducting real-time in situ measurements at an urban/rural pair in Georgia: an Atlanta metropolitan site at Jefferson Street (JST) and a rural site at Yorkville (YRK, also a FRM site) in August of 2008. In the following analysis, online WSOC was expected to be $\mathrm{WSOC}_{\mathrm{NB}}$ since little biomass burning contributions were observed in the southeast during summer (Zhang et al., 2010), although no companion measurements of biomass burning tracers were available.

\subsubsection{Online WSOC measurements at JST and YRK}

For the entire 1-month study, WSOC concentrations (10min averages) at JST and YRK were moderately correlated $\left(r^{2}=0.37\right)$. The time series of WSOC and other associated parameters at JST and YRK are shown in Fig. 8. Between the two sites, WSOC exhibited both common and distinct temporal patterns. On a lower frequency scale ( $\sim$ daily), urban and rural WSOC generally tracked each other well, whereas on a higher frequency scale ( $\sim$ hourly), urban WSOC showed larger and more frequent fluctuations superimposed on the generally less variable lower frequency varying rural WSOC. Since YRK is often located upwind of JST and so is not subject to significant urban impact, as indicated by the consistently lower $\mathrm{CO}$ and $\mathrm{NO}_{\mathrm{x}}$ concentrations (Fig. 8), the more constant YRK WSOC likely represents the typical regional (i.e. rural) background levels, and the smooth variation is due to synoptic meteorological processes. For example, the consistently lower concentrations of a variety of species at both 


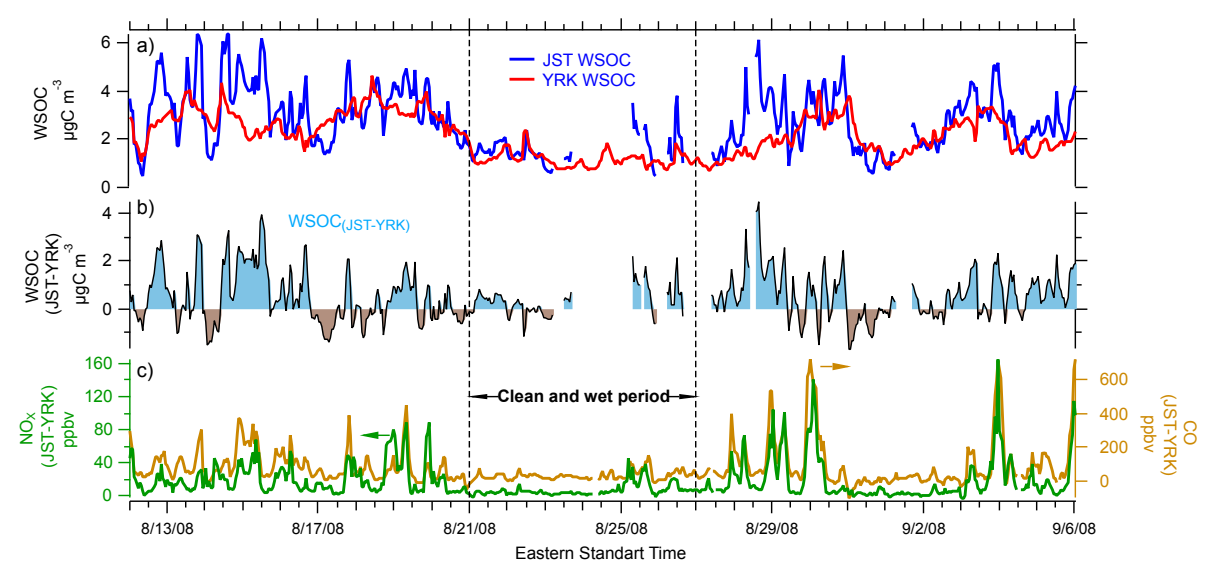

Fig. 8. Time series of WSOC and other parameters measured at Jefferson St. (JST) and Yorkville (YRK) from 12 August 2008 to 6 September 2008 during the AMIGAS field campaign: (a) absolute WSOC concentrations at the two sites; (b) WSOC difference ( $\triangle$ WSOC) between the two sites (i.e. WSOC $\mathrm{JST}_{\text {minus }} \mathrm{WSOC}_{\mathrm{YRK}}$ ); (c) $\mathrm{CO}$ and $\mathrm{NO}_{\mathrm{X}}$ difference between the two sites (i.e. $\mathrm{CO}_{\mathrm{JST}}$ minus $\mathrm{CO}_{\mathrm{YRK}}$, $\mathrm{NO}_{\mathrm{X} \_J S T}$ minus $\mathrm{NO}_{\mathrm{X}_{-} \mathrm{YRK}}$.

sites during 21-26 August were mainly due to higher wind speeds and frequent rain events. The air masses impacting both sites during this period originated either from the Gulf of Mexico or the Atlantic Ocean (Padró et al., 2011). The distinct WSOC pattern at the urban relative to the rural site is likely due to a combination of SOA precursor emissions and chemical formation processes. Based on data from emission inventories, isoprene emissions at these two sites are practically identical (Fig. 6a), indicating that biogenic SOA precursors were not the main reason for the difference. Higher JST WSOC is generally associated with much higher CO and $\mathrm{NO}_{\mathrm{x}}$ levels and lower wind speeds at the urban site (not plotted), indicating local production of WSOC under anthropogenic influence. Occasionally, YRK WSOC was higher (e.g. on 14, 17, 31 August 2008) due to stagnation events.

Average diurnal trends for $\mathrm{CO}, \mathrm{O}_{3}$ and WSOC at JST and YRK also showed distinctly different patterns at these two sites (Fig. 9a, b). WSOC and CO at YRK were nearly constant throughout the day. In contrast, JST CO clearly showed a characteristic morning rush hour peak at $\sim$ 07:00 a.m. and roughly a factor of 2 night-to-day enhancement, which was attributed to lower nighttime mixed layer height leading to higher $\mathrm{CO}$ concentrations from nighttime mobile source emissions. JST WSOC was constantly higher than YRK, again indicating the urban enhancement of SOA formation. Primary WSOC emissions can also make some contribution, as seen by the morning WSOC peak during rush hour, but this was clearly minor compared to secondary photochemical production when considering the effect of mixed layer expansion. As a rough approximation, the effect of expanding mixed layer on WSOC variation can be determined by normalizing WSOC concentration to a conservative species (e.g. $\mathrm{CO})$. Figure $9 \mathrm{c}$ shows the diurnal profile of $\Delta \mathrm{WSOC} / \Delta \mathrm{CO}$ $\left(=\mathrm{WSOC}_{\text {(JST-YRK) }} /\left(\mathrm{CO}_{\text {JST }}-0.15 \mathrm{ppmv}\right)\right.$, where it assumes the CO emissions at JST are constant throughout the day (a significant over-simplification) and a CO background level of $0.15 \mathrm{ppmv}$ (based on $\mathrm{CO}_{\mathrm{YRK}}$ ). The result shows that the major source of urban excess WSOC is photochemical production (i.e. $\triangle$ WSOC / $\triangle \mathrm{CO}$ tracks solar radiation and $\mathrm{O}_{3}$ concentrations), which is much more significant than the mobile emissions leading to primary WSOC during morning rush hour. An alternate approach to estimate the urban $\Delta$ WSOC production is to use the actual mixed layer height, in which case the column integrated WSOC concentration can be calculated by multiplying $\triangle \mathrm{WSOC}$ concentrations by the mixed layer height. This product is directly related to the urban WSOC source per unit surface area, assuming that WSOC concentrations above the mixed layer are negligible, no net advection of WSOC into the region or loss of WSOC by deposition to the surface, and WSOC within the mixed layer is uniformly distributed. Mixed layer heights were not measured during the AMIGAS study, so literature values reported by Marsik et al. (1995) were used instead. Figure $9 \mathrm{c}$ shows that the two approaches give similar diurnal profiles, both characterizing the photochemical production with normalized WSOC concentrations peaking at approximately 15:00 local time, roughly $1-2 \mathrm{~h}$ later than when solar intensity reached its maximum value. The rate of increase in WSOC per unit surface area from morning to early afternoon (i.e. increasing slope of WSOC column) gave an average urban WSOC production rate during this time period of approximately $0.55 \mathrm{mgC} \mathrm{m}^{-2} \mathrm{~h}^{-1}$, or $1.1 \mathrm{mg} \mathrm{m}^{-2} \mathrm{~h}^{-1}$ for WSOM mass (shown as the red dotted line in Fig. 9c). After the peak near 15:00, both $\triangle \mathrm{WSOC} / \triangle \mathrm{CO}$ and mixed layer $\triangle$ WSOC column decreased to background levels, possibly owing to SOA production weakening and/or downward mixing of cleaner air mass from aloft (Blanchard et al., 2011). At night there was low production of WSOC, indicated by 


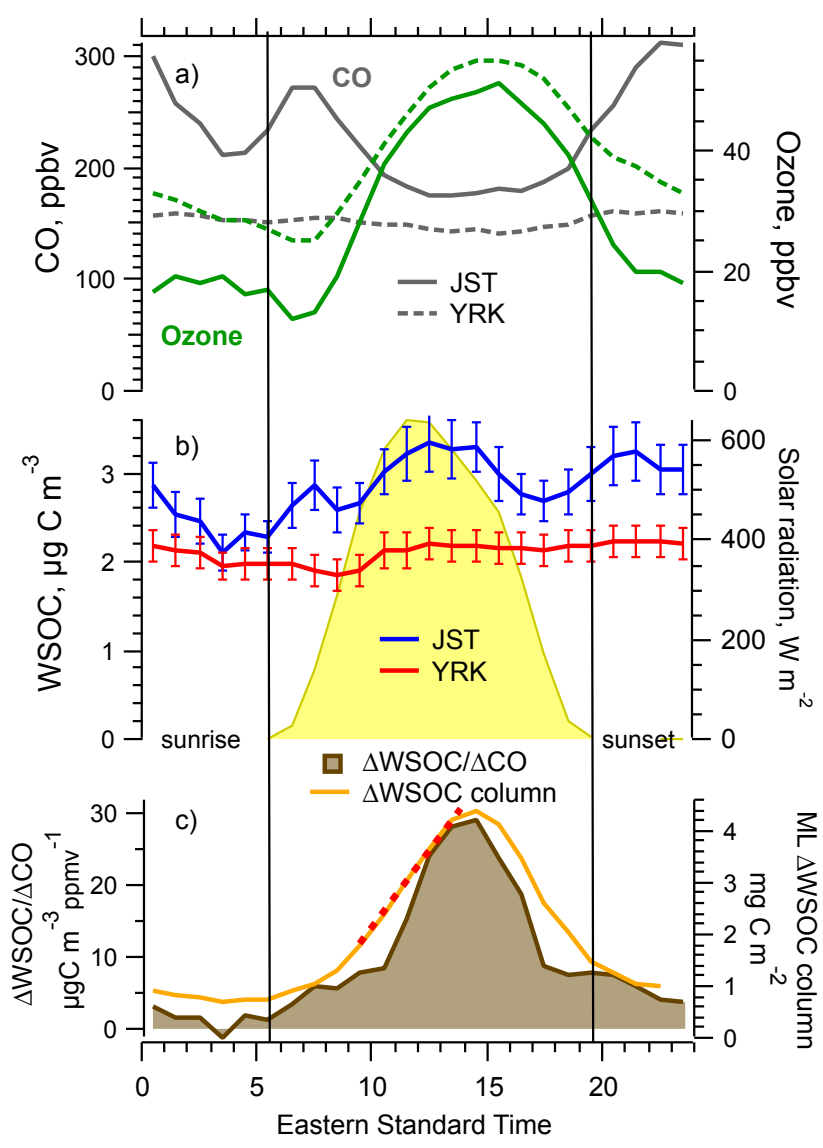

Fig. 9. Composite diurnal profiles of (a) $\mathrm{CO}, \mathrm{O}_{3}$ at JST and YRK, (b) WSOC concentrations at JST and YRK, solar intensity at JST, and (c) $\Delta \mathrm{WSOC} / \triangle \mathrm{CO}$ and mixed layer $\Delta \mathrm{WSOC}$ column, where $\Delta \mathrm{WSOC} / \Delta \mathrm{CO}=\mathrm{WSOC}_{(\mathrm{JST}-\mathrm{YRK})} /(\mathrm{CO}-0.15 \mathrm{ppmv})$, and mixed layer $\Delta$ WSOC column $=\mathrm{WSOC}_{(\mathrm{JST}-\mathrm{YRK})} \times \mathrm{MLH}($ mixed layer height), during the AMIGAS sampling period. The red dotted line in panel (c) represents an estimate of urban WSOC production rate in unit of $\mathrm{mgC} \mathrm{m}^{-2} \mathrm{~h}^{-1}$.

the flat slopes, similar to findings from previous studies on Atlanta WSOC (Hennigan et al., 2009).

The urban/rural comparison suggests that the anthropogenic emissions play an important role in the enhancement of WSOC (SOA) in urban areas. Anthropogenic emissions could be involved in SOA formation in several ways, such as direct contributions from anthropogenic SOA precursors, e.g. aromatics (Henze et al., 2008) and acetylene (Volkamer et al., 2009), evaporation and re-condensation of semi-volatile organic vapors (Robinson et al., 2007; de Gouw et al., 2011), $\mathrm{NO}_{\mathrm{x}}$ effect on both biogenic and anthropogenic SOA yields (Presto et al., 2005; Song et al., 2005; Ng et al., 2007) as well as SOA formed through reaction of $\mathrm{NO}_{3}$ radical with biogenic VOCs (Surratt et al., 2008; Brown et al., 2009). Based on the real-time data, the urban excess WSOC was on average $31 \%$ of the rural (regional) WSOC. However, as shown in Fig. 7, for FRM filter WSOC the urban/rural difference during summer was only $\sim 10 \%$. The inconsistency between filter and online data may be due to the loss of semi-volatile components of the urban excess WSOC from the FRM filters during sampling and storage. Consequently, the FRM WSOC data in both urban and rural areas showed little variation and tend to be highly correlated as discussed in Sect. 3.2.

Considering the urban/rural difference obtained from the online data, it is of interest how anthropogenic emissions were involved in the formation of urban WSOC in Atlanta. Zhang et al. (2011) observed a similar average WSOC diurnal profile as shown in Fig. 9 in Atlanta in the summer of 2010. Meanwhile, they made measurements of WSOC light absorption in Atlanta and Los Angeles and found that the freshly-formed urban WSOC (i.e. $\triangle$ WSOC) in Atlanta was much less light-absorbing ( $\sim 4-6$ times less) than those freshly formed in LA. The LA $\triangle \mathrm{WSOC}$ is proved to be mainly from anthropogenic sources (Zhang et al., 2011; Bahreini et al., 2012). As an approximation, taking lightabsorbing WSOC as a measure of anthropogenic SOA suggests that in Atlanta up to $25 \%$ of the urban $\triangle$ WSOC was from direct contributions of anthropogenic VOCs, and the rest $(75 \%)$ was related to formation of biogenic SOA, possibly enhanced under anthropogenic influence.

\subsection{Sources of summertime regional FRM WSOC}

A Positive Matrix Factorization (PMF) analysis using the FRM PM 2.5 chemical composition (WSOC, $\mathrm{Na}^{+}, \mathrm{NH}_{4}^{+}, \mathrm{K}^{+}$, $\mathrm{Mg}^{2+}, \mathrm{SO}_{4}^{2-}$, oxalate, xylose, and levoglucosan) and light absorption data set from all 15 sites was performed to investigate the sources of $\mathrm{PM}_{2.5}$ throughout the southeast region over the year of 2007. A detailed description and procedures for the PMF analysis were presented elsewhere (Zhang et al., 2010; Hecobian et al., 2010). PMF results focusing on summertime FRM WSOC formation processes are discussed here.

Four factors were resolved by PMF from the full year data set that included all 15 FRM sites. Factor 1 and 2 (F1 and F2) were related to biomass burning and refractory materials, respectively. Factors 3 and 4 (F3 and F4) were associated with secondary processes, indicated by their highest relative contributions to $\mathrm{PM}_{2.5}$ mass in summer and loadings of known secondary components (WSOC, sulfate and oxalate). F3 is characterized mainly by high loadings of WSOC, oxalate and water-soluble organic species that absorb light at $365 \mathrm{~nm}$ (i.e. soluble brown carbon, $b_{\text {ap365 }}$ ) (Fig. 10a). This factor explains most of the variability of WSOC and oxalate ( $56 \%$ for each), and $25 \%$ of the variability of brown carbon ( $b_{\text {ap365 }}$ ) in the year of 2007 (Fig. 10b); the lower fraction of $b_{\text {ap365 }}$ associated with this factor is due to its main source being biomass burning emission (Hecobian et al., 2010). F4 is characterized by high loadings of $\mathrm{NH}_{4}^{+}(86 \%)$ and $\mathrm{SO}_{4}^{2-}$ $(90 \%)$ and a moderate amount of WSOC, which accounted for $22 \%$ of its yearly variability (Fig. 10b). Another PMF analysis performed on the sub data set from the 8 CSN sites 
a)
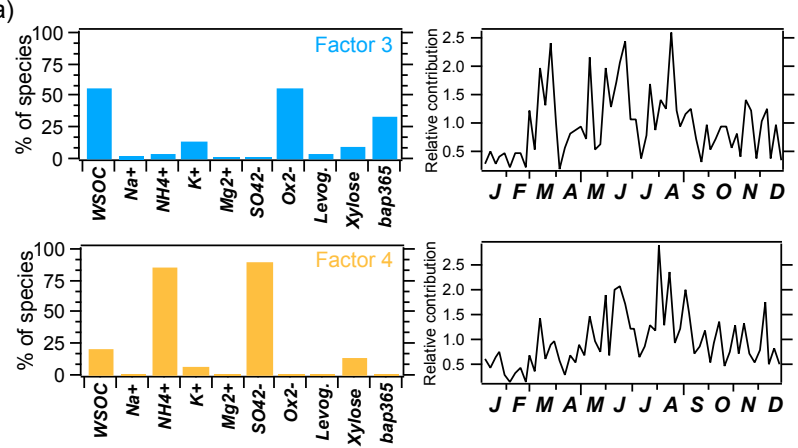

b)

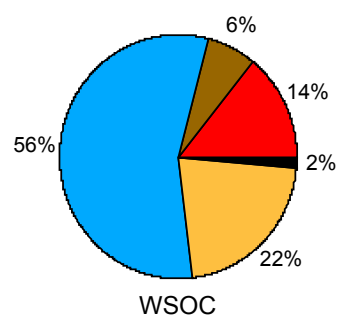

F1 - biomass burning

F3 - secondary light absorbing WSOC

F4 - secondary sulfate/WSOC

residual

Fig. 10. Results from PMF analysis detailed by Zhang et al. (2010) showing: (a) composition profiles and relative contributions of factors 3 and 4 throughout the year of 2007, and (b) average loading of WSOC and oxalate amongst the four PMF factors.

including additional data (i.e. OC, EC, and metals) resolved an additional factor that was associated with mobile source (Zhang et al., 2010; Hecobian et al., 2010). However, the results related to F3 and F4 and their relative contributions in the summer remain similar to the four-factor PMF analysis discussed here.

The very different composition profiles of F3 and F4 suggest different physical and/or chemical processes involved in the regional WSOC (SOA) formation. The limited number of species available for this factor analysis limits the identification of multiple sources and prohibits definitive identification of the sources or processes leading to these two factors, but the differences between F3 and F4 are intriguing. In the following we speculate on possible sources of the regional WSOC in the southeast.

Factor 3: the association among oxalate, $b_{\text {ap } 365}$ and WSOC of F3 is notable for a number of reasons. First, these are all characteristics of biomass burning emissions (Factor 1 detailed by Zhang et al., 2010). Although biomass burning cannot be completely ruled out, it is unlikely to cause such a large fraction of the summertime FRM WSOC variability. Instead, numerous laboratory studies have shown that chemical processes in aqueous solutions produce both oxalate (Sorooshian et al., 2006; Lim et al., 2010) and light-

absorbing organic compounds (Bones et al., 2010; Sareen et al., 2010), along with other aqueous SOA products including oligomers and high molecular weight multi-functional compounds that could be included in the overall WSOC in F3 (Surratt et al., 2007; Nguyen et al., 2012). Collectively, these components have been grouped as HULIS (de Haan et al., 2009; Shapiro et al., 2009) and are linked to aqueous chemical aging of the aerosol, which uniquely explains the presence of high MW compounds (Ervens et al., 2011). Gao et al. (2006) have detected polar organics that are similar to HULIS on filters collected in rural areas in the southeast and have shown evidence of atmospheric processing of biogenic emissions leading to HULIS as a typical pathway in the background (regional) atmosphere. Hennigan et al. (2009) and Zhang et al. (2012) studied WSOC gas/particle partitioning in urban Atlanta and found evidence for WSOC partitioning to particle liquid water indicating that an aqueous chemical route is feasible. The fact that the PMF factor $3 \mathrm{ex}-$ plains much of the variability of WSOC mass concentrations suggests the importance of a potential summertime aqueous WSOC formation route.

Factor 4: previous aerosol source apportionment studies in the southeast and other locations have attributed factors with high organic carbon and ammonium sulfate loadings to be associated with secondary aerosol formation through a variety of pathways. Correlations between WSOC and sulfate in some locations show clear evidence for a cloud formation process (Huang et al., 2006); however, the lack of oxalate associated with F4 seems to suggest this may not be the case in the southeast. WSOC-sulfate correlations may result from possible acid-catalyzed effects on SOA formation (Liu et al., 2005; Kim and Hopke, 2006), or simply could be related to long-range transport (Saarikoski et al., 2008). We have noted the spatial and seasonal correlations of WSOC and sulfate and attributed some of this co-variability to both being secondary components with similar atmospheric lifetimes/loss processes. This would be consistent with $\mathrm{F} 4$ representing the regional/more aged aerosols mainly composed of sulfate and WSOC. A more comprehensive data set that includes speciated SOA tracer compounds (e.g. IEPOX and other known monoterpene, sesquiterpene, and aromatic tracers) as well as high-resolution aerosol mass spectrometry (HR-AMS) and VOC/SVOC data is needed to better resolve the causes for differences between F3 and F4.

\section{Conclusions}

The spatial and seasonal variations of WSOC from the FRM filter samples (referred to as FRM WSOC) associated with fine aerosols in the southeastern US were investigated through analysis of over 900 24-h integrated FRM Teflon filters collected from 15 urban and rural sites in 3 states in the year of 2007. FRM WSOC was contrasted with sulfate to examine the possible causes of the observed spatial and 
seasonal patterns. Online measurements of WSOC in August 2008 at an urban/rural pair were compared to the FRM filter urban/rural differences and used for a more detailed analysis of the observed urban excess WSOC. The major findings of this study are:

1. In the southeast, FRM $\mathrm{PM}_{2.5}$ was mainly composed of organic aerosol and ammonium sulfate. On average, OM (1.6 times OC) and ammonium sulfate accounted for $39 \%$ and $50 \%$ of the total $\mathrm{PM}_{2.5}$ mass, respectively. Excluding biomass burning contributions (levoglucosan $<50 \mathrm{ng} \mathrm{m}^{-3}$ ), FRM PM 2.5 mass was tightly correlated with both WSOC ( $r^{2}$ of 0.70 urban, 0.75 rural) and sulfate ( $r^{2}$ of 0.60 urban, 0.66 rural). WSOM (2.0 times WSOC) and ammonium sulfate together contributed up to $71 \%$ at urban and $78 \%$ at rural sites of the total $\mathrm{PM}_{2.5}$ mass, indicating secondary processes largely influenced and substantially contributed to the fine particle loadings over the region throughout the year of 2007.

2. Pronounced seasonality was observed for FRM WSOC and sulfate. Both components showed maximum concentrations in the summer, apparently due to enhanced photochemistry and meteorology associated with elevated temperatures. Enhanced emissions of precursor compounds, such as biogenic hydrocarbons, may also have contributed to the seasonality of WSOC, but links to biogenic emissions and temperature were not as clear since both sulfate and WSOC responded in a similar way.

3. FRM WSOC and sulfate were widely distributed and fairly spatially uniform throughout the southeast, indicated by the significant site-to-site co-variability. Given the point source nature of sulfate precursor $\left(\mathrm{SO}_{2}\right)$, the large scale spatial homogeneity suggested that the dominant role played by secondary components in $\mathrm{PM}_{2.5}$ mass (ignoring biomass burning contributions present mainly in winter) combined with meteorology (a wellmixed region with limited ventilation) was the major cause for the large regional aerosol loading. Spatial uniformity cannot be mainly attributed to a widely distributed source of biogenic precursor VOCs. However, on smaller scales, spatial distributions of estimated isoprene emissions were consistent with relatively small differences in FRM WSOC, providing evidence of biogenic hydrocarbons as important SOA precursors.

4. Online measurements of WSOC between an urban/rural pair (Atlanta/Yorkville) indicated that on average urban WSOC was $31 \%$ higher than rural levels during the sampling period. The urban excess WSOC was clearly associated with local anthropogenic emissions since the WSOC enhancement was linked to $\mathrm{CO}$ and $\mathrm{NO}_{\mathrm{x}}$. In contrast, FRM WSOC urban/rural difference in summer was only $\sim 10 \%$, indicating that filters tend to produce a more uniform distribution, possibly due to poor temporal resolution and loss of semi-volatile organic species that were more likely associated with urban environments. Using the difference between the urbanrural WSOC and estimated boundary layer height, an urban Atlanta WSOC production rate in August was calculated to be roughly $0.55 \mathrm{mgC} \mathrm{m}^{-2} \mathrm{~h}^{-1}$ from morning to mid-afternoon.

5. A PMF analysis was preformed on FRM filter data to investigate the sources of the regional FRM WSOC. Two factors were resolved that explained most (78\%) of the FRM WSOC variability. One factor that explained over half of the 2007 FRM WSOC variability was loaded with oxalate and brown carbon, consistent with a condensed phase SOA formation route. The other factor that accounted for roughly $1 / 4$ of the FRM WSOC variability was associated with ammonium sulfate and may represent a regional aged SOA, or a possible acid catalyzed route. Further work is needed to investigate these hypotheses.

Acknowledgements. This work was supported by GA DNR under grant No. 773-80150 and National Science Foundation grants ATM-0802237 and ATM-0931492. Online WSOC measurements were made as part of the AMIGAS study and were supported by the Electric Power Research Institute (EPRI) and the Southern Company. The authors thank Susan Zimmer-Dauphinee of the Georgia Department of Natural Resources (GA DNR), Tracy Anderson of the Alabama Department of Environmental Management, Randy Dillard of the Alabama Jefferson Co. Department of Health, and Scott Reynolds of the South Carolina Department of Health and Environmental Control for providing the FRM filters. The authors also thank Jiumeng Liu and Thomas Muccillo for assistance in measurements of WSOC and light absorption spectra. The information expressed in this paper does not necessarily reflect the policies of the US Environmental Protection Agency.

Edited by: N. M. Donahue

\section{References}

Bahreini, R., Middlebrook, A. M., de Gouw, J. A., Warneke, C., Trainer, M., Brock, C. A., Brown, S. S., Dube, W. P., Gilman, J. B., Hall, K., Holloway, J. S., Kuster, W. C., Perring, A. E., Prevot, A. S. H., Schwarz, J. P., Spackman, J. R., Stark, H., Szidat, S., Wagner, N. L., Weber, R. J., Zotter P., and Parrish, D. D.: Major contribution from gasoline emissions to secondary organic aerosol mass in the Los Angeles Basin, Geophys. Res. Lett., 39, L06805, doi:10.1029/2011GL050718, 2012.

Bench, G., Fallon, S., Schichtel, B., Malm, W., and McDade, C.: Relative contribution of fossil and contemporary carbon sources to $\mathrm{PM}_{2.5}$ aerosol in nine Interagency Monitoring for Protected 
Visual Environments (IMPROVE) network sites, J. Geophys. Res., 112, D10205, doi:10.1029/2006JD007708, 2007.

Blanchard, C. L., Hidy, G. M., Tanenbaum, S., and Edgerton, E. S.: NMOC, ozone, and organic aerosol in the southeastern United States, 1999-2007: 3. Origins of organic aerosol in Atlanta, Georgia, and surrounding areas, Atmos. Environ., 45, 12911302, 2011.

Bones, D. L., Henricksen, D. K., Mang, S. A., Gonsior, M., Bateman, A. P., Nguyen, T. B., Cooper, W. J., and Nizkorodov, S. A.: Appearance of strong absorbers and fluorophores in limonene$\mathrm{O}_{3}$ secondary organic aerosol due to $\mathrm{NH}_{4}{ }^{+}$-mediated chemical aging over long time scales, J. Geophys. Res., 115, D05203, doi:10.1029/2009JD012864, 2010.

Brown, S. S., de Gouw, J. A., Warneke, C., Ryerson, T. B., Dubé, W. P., Atlas, E., Weber, R. J., Peltier, R. E., Neuman, J. A., Roberts, J. M., Swanson, A., Flocke, F., McKeen, S. A., Brioude, J., Sommariva, R., Trainer, M., Fehsenfeld, F. C., and Ravishankara, A. R.: Nocturnal isoprene oxidation over the Northeast United States in summer and its impact on reactive nitrogen partitioning and secondary organic aerosol, Atmos. Chem. Phys., 9, 30273042, doi:10.5194/acp-9-3027-2009, 2009.

Carrico, C. M., Bergin, M. H., Xu, J., Baumann, K., and Maring, H.: Urban aerosol radiative properties: Measurement during the 1999 Atlanta Supersite Experiment, J. Geophys. Res., 108, 8422, doi:10.1029/2001JD001222, 2003.

Chan, A. W. H., Chan, M. N., Surratt, J. D., Chhabra, P. S., Loza, C. L., Crounse, J. D., Yee, L. D., Flagan, R. C., Wennberg, P. O., and Seinfeld, J. H.: Role of aldehyde chemistry and $\mathrm{NO}_{\mathrm{x}}$ concentrations in secondary organic aerosol formation, Atmos. Chem. Phys., 10, 7169-7188, doi:10.5194/acp-10-7169-2010, 2010a.

Chan, M. N., Surratt, J. D., Claeys, M., Edgerton, E. S., Tanner, R. L., Shaw, S. L., Zheng, M., Knipping, E. M., Eddingsaas, N. C., Wennberg, P. O., and Seinfeld, J. H.: Characterization and quantification of isoprene-derived epoxydiols in ambient aerosol in the southeastern United States, Environ. Sci. Technol., 44, 45904596, 2010b.

Cohan, D. S., Boylan, J. W., Marmur, A., and Khan, M. N.: An integrated framework for multipollutant air quality management and its appliation in Georgia, Environ. Manage., 40, 545-554, 2007.

de Gouw, J. A., Middlebrook, A. M., Warneke, C., Goldan, P. D., Kuster, W. C., Roberts, J. M., Fehsenfeld, F. C., Worsnop, D. R., Canagaratna, M. R., Pszenny, A. A. P., Keene, W. C., Marchewka, M., Bertman, S. B., and Bates, T. S.: Budget of organic carbon in a polluted atmosphere: Results from the New England Air Quality Study in 2002, J. Geophys. Res., 110, D16305, doi:10.1029/2004jd005623, 2005.

de Gouw, J. A., Brock, C. A., Atlas, E. L., Bates, T. S., Fehsenfeld, F. C., Goldan, P. D., Holloway, J. S., Kuster, W. C., Lerner, B. M., Matthew, B. M., Middlebrook, A. M., Onasch, T. B., Peltier, R. E., Quinn, P. K., Senff, C. J., Stohl, A., Sullivan, A. P., Trainer, M., Warneke, C., Weber, R. J., and Williams, E. J.: Sources of particulate matter in the northeastern United States in summer: 1. Direct emissions and secondary formation of organic matter in urban plumes, J. Geophys. Res., 113, D08301, doi:10.1029/2007jd009243, 2008.

de Gouw, J. A., Middlebrook, A. M., Warneke, C., Ahmadov, R., Atlas, E. L., Bahreini, R., Blake, D. R., Brock, C. A., Brioude, J., Fahey, D. W., Fehsenfeld, F. C., Holloway, J. S., Le Henaff,
M., Lueb, R. A., McKeen, S. A., Meagher, J. F., Murphy, D. M., Paris, C., Parrish, D. D., Perring, A. E., Pollack, I. B., Ravishankara, A. R., Robinson, A. L., Ryerson, T. B., Schwarz, J. P., Spackman, J. R., Srinivasan, A., and Watts, L. A.: Organic aerosol formation downwind from the Deepwater Horizon oil spill, Science, 331, 1295-1299, 2011.

de Haan, D. O., Tolbert, M. A., and Jimenez, J. L.: Atmospheric condensed-phase reactions of glyoxal with methylamine, Geophys. Res. Lett., 36, L11819, doi:11810.11029/12009GL037441, 2009.

Ding, X., Zheng, M., Yu, L. P., Zhang, X. L., Weber, R. J., Yan, B., Russell, A. G., Edgerton, E. S., and Wang, X. M.: Spatial and seasonal trends in biogenic secondary organic aerosol tracers and water-soluble organic carbon in the southeastern United States, Environ. Sci. Technol., 42, 5171-5176, 2008.

Dommen, J., Metzger, A., Duplissy, J., Kalberer, M., Alfarra, M. R., Gascho, A., Weingartner, E., Prevot, A. S. H., Verheggen, B., and Baltensperger, U.: Laboratory observation of oligomers in the aerosol from isoprene/ $\mathrm{NO}_{\mathrm{x}}$ photooxidation, Geophys. Res. Lett., 33, L13805, doi:10.1029/2006gl026523, 2006.

Eatough, D. J., Wadsworth, A., Eatough, D. A., Crawford, J. W., Hansen, L. D., and Lewis, E. A.: A multiple-system, multichannel diffusion denuder sampler for the determination of fine particulate organic material in the atmosphere, Atmos. Environ., 27, 1213-1219, 1993.

Ervens, B., Carlton, A. G., Turpin, B. J., Altieri, K. E., Kreidenweis, S. M., and Feingold, G.: Secondary organic aerosol yields from cloud-processing of isoprene oxidation products, Geophys. Res. Lett., 35, L02816, doi:10.1029/2007GL031828, 2008.

Ervens, B., Turpin, B. J., and Weber, R. J.: Secondary organic aerosol formation in cloud droplets and aqueous particles (aqSOA): a review of laboratory, field and model studies, Atmos. Chem. Phys., 11, 11069-11102, doi:10.5194/acp-1111069-2011, 2011.

Gao, S., Surratt, J. D., Knipping, E. M., Edgerton, E. S., Shahgholi, M., and Seinfeld, J. H.: Characterization of polar organic components in fine aerosols in the southeastern United States: Identity, origin, and evolution, J. Geophys. Res., 111, D14314, doi:10.1029/2005JD006601, 2006.

Goldstein, A. H., Koven, C. D., Heald, C. L., and Fung, I. Y.: Biogenic carbon and anthropogenic pollutants combine to form a cooling haze over the southeastern United States, P. Natl. Acad. Sci., 106, 8835-8840, doi:10.1073/PNAS.0904128106, 2009.

Guenther, A., Karl, T., Harley, P., Wiedinmyer, C., Palmer, P. I., and Geron, C.: Estimates of global terrestrial isoprene emissions using MEGAN (Model of Emissions of Gases and Aerosols from Nature), Atmos. Chem. Phys., 6, 3181-3210, doi:10.5194/acp-63181-2006, 2006.

Hand, J. L., Schichtel, B. A., Pitchford, M., Malm, W. C., and Frank, N. H.: Seasonal composition of remote and urban fine particulate matter in the United States, J. Geophys. Res., 117, D05209, doi:10.1029/2011JD017122, 2012.

Hansen, O. A., Edgerton, E. S., Hartsell, B. E., Jansen, J. J., Kandasamy, N., Hidy, G. M., and Blanchard, C. L.: The southeastern aerosol research and characterization study: Part 1-Overview, J. Air Waste Manage. Assoc., 53, 1460-1471, 2003.

Hecobian, A., Zhang, X., Zheng, M., Frank, N., Edgerton, E. S., and Weber, R. J.: Water-Soluble Organic Aerosol material and the light-absorption characteristics of aqueous extracts measured 
over the Southeastern United States, Atmos. Chem. Phys., 10, 5965-5977, doi:10.5194/acp-10-5965-2010, 2010.

Hennigan, C. J., Bergin, M. H., Russell, A. G., Nenes, A., and Weber, R. J.: Gas/particle partitioning of water-soluble organic aerosol in Atlanta, Atmos. Chem. Phys., 9, 3613-3628, doi:10.5194/acp-9-3613-2009, 2009.

Hennigan, C. J., Sullivan, A. P., Collett Jr., J. L., and Robinson, A. L.: Levoglucosan stability in biomass burning particles exposed to hydroxyl radicals, Geophys. Res. Lett., 37, L09806, doi:10.1029/2010GL043088, 2010.

Henze, D. K., Seinfeld, J. H., Ng, N. L., Kroll, J. H., Fu, T.-M., Jacob, D. J., and Heald, C. L.: Global modeling of secondary organic aerosol formation from aromatic hydrocarbons: highvs. low-yield pathways, Atmos. Chem. Phys., 8, 2405-2420, doi:10.5194/acp-8-2405-2008, 2008.

Hoffmann, T., Odum, J. R., Bowman, F., Collins, D., Klockow, D., Flagan, R. C., and Seinfeld, J. H.: Formation of organic aerosols from the oxidation of biogenic hydrocarbons, J. Atmos. Chem., 26, 189-222, 1997.

Huang, X.-F., Yu, J. Z., He, L.-Y., and Yuan, Z.: Watersoluble organic carbon and oxalate in aerosols at a coastal urban site in China: Size distribution characteristics, sources, and formation mechanisms, J. Geophys. Res., 111, D22212, doi:10.1029/2006jd007408, 2006.

IPCC: Fourth Assessment Record: Climate change 2007, Cambridge University Press, New York, 2007.

Kim, E. and Hopke, P. K.: Characterization of ?ne particle sources in the Great Smoky Mountains area, Sci. Total Environ., 368, 781-794, 2006.

Kroll, J. H., Ng, N. L., Murphy, S. M., Flagan, R. C., and Seinfeld, J. H.: Secondary organic aerosol formation from isoprene photooxidation, Environ. Sci. Technol., 40, 1869-1877, 2006.

Lee, S., Wang, Y., and Russell, A. G.: Assessment of secondary organic carbon in the southeastern United States: a review, J. Air Waste Manage., 60, 1282-1292, 2010.

Lim, H. J. and Turpin, B. J.: Origins of primary and secondary aerosol in Atlanta: Results of time-resolved measurements during the Atlanta Supersite Experiment, Environ. Sci. Technol., 36, 4489-4496, 2002.

Lim, Y. B., Tan, Y., Perri, M. J., Seitzinger, S. P., and Turpin, B. J.: Aqueous chemistry and its role in secondary organic aerosol (SOA) formation, Atmos. Chem. Phys., 10, 1052110539, doi:10.5194/acp-10-10521-2010, 2010.

Lin, Y.-H., Zhang, Z., Docherty, K. S., Zhang, H., Budisulistiorini, S. H., Rubitschun, C. L., Shaw, S. L., Knipping, E. M., Edgerton, E. S., Kleindienst, T. E., Gold, A., and Surratt, J. D.: Isoprene epoxydiols as precursors to secondary organic aerosol formation: Acidcatalyzed reactive uptake studies with authentic compounds, Environ. Sci. Technol., 46, 250-258, 2012.

Liu, W., Wang, Y., Russell, A., and Edgerton, E. S.: Atmospheric aerosol over two urban-rural pairs in the southeastern United States: Chemical composition and possible sources, Atmos. Environ., 39, 4453-4470, 2005.

Marsik, F. J., Fischer, K. W., McDonald, T. D., and Samson, P. J.: Comparison of methods for estimating mixing height used during the 1992 Atlanta Field Intensive, J. Appl. Meteorol., 34, 18021814, 1995.

Miyazaki, Y., Kondo, Y., Shiraiwa, M., Takegawa, N., Miyakawa, T., Han, S., Kita, K., Hu, M., Deng, Z. Q., Zhao, Y., Sugimoto,
N., Blake, D. R., and Weber, R. J.: Chemical characterization of water-soluble organic carbon aerosols at a rural site in the Pearl River Delta, China, in the summer of 2006, J. Geophys. Res., 114, D14208, doi:10.1029/2009JD011736, 2009.

Müller, J.-F., Stavrakou, T., Wallens, S., De Smedt, I., Van Roozendael, M., Potosnak, M. J., Rinne, J., Munger, B., Goldstein, A., and Guenther, A. B.: Global isoprene emissions estimated using MEGAN, ECMWF analyses and a detailed canopy environment model, Atmos. Chem. Phys., 8, 1329-1341, doi:10.5194/acp-81329-2008, 2008.

Ng, N. L., Kroll, J. H., Chan, A. W. H., Chhabra, P. S., Flagan, R. C., and Seinfeld, J. H.: Secondary organic aerosol formation from m-xylene, toluene, and benzene, Atmos. Chem. Phys., 7, 3909-3922, doi:10.5194/acp-7-3909-2007, 2007.

Nguyen, T. B., Lee, P. B., Updyke, K. M., Bones, D. L., Laskin, J., Laskin, A., and Nizkorodov, S. A.: Formation of nitrogenand sulphur-containing light-absorbing compounds accelerated by evaporation of water from secondary organic aerosols, J. Geophys. Res., 117, D01207, doi:10.1029/2011JD016944, 2012.

Odum, J. R., Jungkamp, T. P. W., Griffin, R. R., Flagan, R. C., and Seinfeld, J. H.: The atmospheric aerosol-forming potential of whole gasoline vapour, Science, 276, 96-99, 1997.

Padró, L. T., Moore, R. H., Zhang, X., Rastogi, N., Weber, R. J., and Nenes, A.: Mixing state and compositional effects on CCN activity and droplet growth kinetics of size-resolved $\mathrm{CCN}$ in an urban environment, Atmos. Chem. Phys. Discuss., 11, 3272332768, doi:10.5194/acpd-11-32723-2011, 2011.

Portmann, R. W., Solomon, S., and Hegerl, G. C.: Spatial and seasonal patterns in climate change, temperatures, and precipitation across the United States, P. Natl. Acad. Sci., 106, 7324-7329, 2009.

Presto, A. A., Hartz, K. E. H., and Donahue, N. M.: Secondary organic aerosol production from terpene ozonolysis. 2. Effect of $\mathrm{NO}_{\mathrm{x}}$ concentration, Environ. Sci. Technol., 39, 7046-7054, 2005.

Robinson, A. L., Donahue, N. M., Shrivastava, M. K., Weitkamp, E. A., Sage, A. M., Grieshop, A. P., Lane, T. E., Pierce, J. R., and Pandis, S. N.: Rethinking organic aerosols: semivolatile emissions and photochemical aging, Science, 315, 1259-1262, 2007.

Saarikoski, S., Timonen, H., Saarnio, K., Aurela, M., Järvi, L., Keronen, P., Kerminen, V.-M., and Hillamo, R.: Sources of organic carbon in fine particulate matter in northern European urban air, Atmos. Chem. Phys., 8, 6281-6295, doi:10.5194/acp-86281-2008, 2008.

Sareen, N., Schwier, A. N., Shapiro, E. L., Mitroo, D., and McNeill, V. F.: Secondary organic material formed by methylglyoxal in aqueous aerosol mimics, Atmos. Chem. Phys., 10, 997-1016, doi:10.5194/acp-10-997-2010, 2010.

Schichtel, B. A., Malm, W. C., Bench, G., Fallon, S., McDade, C. E., Chow, J. C., and Watson, J. G.: Fossil and contemporary fine particulate carbon fractions at 12 rural and urban sites in the United States, J. Geophys. Res., 113, D02311, doi:10.1029/2007JD008605, 2007.

Shapiro, E. L., Szprengiel, J., Sareen, N., Jen, C. N., Giordano, M. R., and McNeill, V. F.: Light-absorbing secondary organic material formed by glyoxal in aqueous aerosol mimics, Atmos. Chem. Phys., 9, 2289-2300, doi:10.5194/acp-9-2289-2009, 2009.

Song, C., Na, K. S., and Cocker, D. R.: Impact of the hydrocarbon to $\mathrm{NO}_{\mathrm{x}}$ ratio on secondary organic aerosol formation, Environ. 
Sci. Technol., 39, 3143-3149, 2005.

Sorooshian, A., Brechtel, F. J., Ervens, B., Feingold, G., Varutbangkul, V., Bahreini, R., Murphy, S., Holloway, J. S., Atlas, E. L., Anlauf, K., Buzorius, G., Jonsson, H., Flagan, R. C., and Seinfeld, J. H.: Oxalic acid in clear and cloudy atmospheres: Analysis of data from International Consortium for Atmospheric Research on Transport and Transformation 2004, J. Geophys. Res., 111, D23S45, doi:10.1029/2005JD006880, 2006.

Sullivan, A. P., Weber, R. J., Clements, A. L., Turner, J. R., Bae, M. S., and Schauer, J. J.: A method for on-line measurement of water-soluble organic carbon in ambient aerosol particles: Results from an urban site, Geophys. Res. Lett., 31, L13105, doi:10.1029/2004GL019681, 2004.

Sullivan, A. P., Peltier, R. E., Brock, C. A., de Gouw, J. A., Holloway, J. S., Warneke, C., Wollny, A. G., and Weber, R. J.: Airborne measurements of carbonaceous aerosol soluble in water over northeastern United States: Method development and an investigation into water-soluble organic carbon sources, J. Geophys. Res., 111, D23S46, doi:10.1029/2006JD007072, 2006.

Surratt, J. D., Kroll, J. H., Kleindienst, T. E., Edney, E. O., Claeys, M., Sorooshian, A., Ng, N. L., Offenberg, J. H., Lewandowski, M., Jaoui, M., Flagan, R. C., and Seinfeld, J. H.: Evidence for organosulfates in secondary organic aerosol, Environ. Sci. Technol., 41, 517-527, 2007.

Surratt, J. D., Gomez-Gonzalez, Y., Chan, A. W. H., Vermeylen, R., Shahgholi, M., Kleindienst, T. E., Edney, E. O., Offenberg, J. H., Lewandowski, M., Jaoui, M., Maenhaut, W., Claeys, M., Flagan, R. C., and Seinfeld, J. H.: Organosulfate formation in biogenic secondary organic aerosol, J. Phys. Chem. A, 112, 8345-8378, 2008.

Tan, Y., Carlton, A. G., Seitzinger, S. P., and Turpin, B. J.: SOA from methylglyoxal in clouds and wet aerosols: Measurement and prediction of key products, Atmos. Environ., 44, 5218-5226, 2010.

Tanner, R. L., Parkhurst, W. J., Valente, M. L., and Phillips, W. D.: Regional composition of $\mathrm{PM}_{2.5}$ aerosols measured at urban, rural and "background" sites in the Tennessee valley, Atmos. Environ., 38, 3143-3153, 2004.

Turpin, B. J. and Lim, H.-J.: Species contributions to $\mathrm{PM}_{2.5}$ mass concentrations: Revisiting common assumptions for estimating organic mass, Aerosol Sci. Technol., 35, 602-610, 2001.

Volkamer, R., Ziemann, P. J., and Molina, M. J.: Secondary Organic Aerosol Formation from Acetylene $\left(\mathrm{C}_{2} \mathrm{H}_{2}\right)$ : seed effect on SOA yields due to organic photochemistry in the aerosol aqueous phase, Atmos. Chem. Phys., 9, 1907-1928, doi:10.5194/acp9-1907-2009, 2009.

Watson, J. G., Chow, J. C., Chen, L. W. A., and Frank, N. H.: Methods to assess carbonaceous aerosol sampling artifacts for IMPROVE and other long-term networks, J. Air Waste Manage. Assoc., 59, 898-911, 2009.
Weber, R. J., Orsini, D., Duan, Y., Baumann, K., Kiang, C. S., Chameides, W., Lee, Y. N., Brechtel, F., Klotz, P., Jongejan, P., ten Brink, H., Slanina, J., Boring, C. B., Genfa, Z., Dasgupta, P., Hering, S., Stolzenburg, M., Dutcher, D. D., Edgerton, E., Hartsell, B., Solomon, P., and Tanner, R.: Intercomparison of near real time monitors of $\mathrm{PM}_{2.5}$ nitrate and sulfate at the U. S. Environmental Protection Agency Atlanta Supersite, J. Geophys. Res., 108, 8421, doi:10.1029/2001JD001220, 2003.

Weber, R. J., Sullivan, A. P., Peltier, R. E., Russell, A., Yan, B., Zheng, M., de Gouw, J., Warneke, C., Brock, C., Holloway, J. S., Atlas, E. L., and Edgerton, E.: A study of secondary organic aerosol formation in the anthropogenicinfluenced southeastern United States, J. Geophys. Res., 112, D13302, doi:10.1029/2007JD008408, 2007.

Worton, D. R., Goldstein, A. H., Farmer, D. K., Docherty, K. S., Jimenez, J. L., Gilman, J. B., Kuster, W. C., de Gouw, J., Williams, B. J., Kreisberg, N. M., Hering, S. V., Bench, G., McKay, M., Kristensen, K., Glasius, M., Surratt, J. D., and Seinfeld, J. H.: Origins and composition of fine atmospheric carbonaceous aerosol in the Sierra Nevada Mountains, California, Atmos. Chem. Phys., 11, 10219-10241, doi:10.5194/acp-1110219-2011, 2011.

Zhang, X., Hecobian, A., Zheng, M., Frank, N. H., and Weber, R. J.: Biomass burning impact on $\mathrm{PM}_{2.5}$ over the southeastern US during 2007: integrating chemically speciated FRM filter measurements, MODIS fire counts and PMF analysis, Atmos. Chem. Phys., 10, 6839-6853, doi:10.5194/acp-10-6839-2010, 2010.

Zhang, X., Lin, Y.-H., Surratt, J. D., Zotter, P., Prévôt, A. H. S., and Weber, R. J.: Light-absorbing soluble organic aerosol in Los Angeles and Atlanta: A contrast in secondary organic aerosol, Geophys. Res. Lett., 38, L21810, doi:10.1029/2011GL049385, 2011.

Zhang, X., Liu, J., Parker, E. T., Hayes, P. L., Jimenez, J. L., de Gouw, J. A., Flynn, J. H., Grossberg, N., Lefer, B. L., and Weber, R. J.: On the gas-particle partitioning of soluble organic aerosol in two urban atmospheres with contracting emissions: Part 1. Bulk water-soluble organic carbon, J. Geophys. Res., in press, 2012.

Zheng, M., Ke, L., Edgerton, E. S., Schauer, J. J., Dong, M. Y., and Russell, A. G.: Spatial distribution of carbonaceous aerosol in the southeastern United States using molecular markers and carbon isotope data, J. Geophys. Res., 111, D10S06, doi:10.1029/2005JD006777, 2006. 